\title{
Voice Features Across Essay Types Among Advanced EFL Learners
}

\author{
Rajab Esfandiari ${ }^{1}$, Hananeh Sharifi ${ }^{2}$
}

1 Imam Khomeini International University Department of English Language, Faculty of Humanities, PC, IRN-34148-96818 Qazvin, Iran, esfandiari@hum.ikiu.ac.ir

2 Imam Khomeini International University, Department of English Language, Faculty of Humanities, PC, IRN-34148-96818 Qazvin, Iran, hannanehsharifi951@gmail.com

Annotation. The present study reports on the findings of voice features across three text types under two different conditions. The results show significant differences in voice features in expository, but not in argumentative and descriptive text types, under timed and untimed conditions. The findings suggest that the analysis of voice features in different text types can inform writers of how successfully they create a balance in introducing their own perspectives.

Keywords: voice feature, essay type, stance, timed essay, untimed essay.

\section{Introduction}

Voice is regarded as one of the critical components in writing, leading students to become familiar with the pedagogical techniques which make them capable of developing control over their identities in a text (Stewart, 1992). As DiPardo et al. (2011) noted, the availability of strong voice develops potentiality for a writer to write honestly with conviction. Thus, this potentiality paves the way for a reader to be equipped to the sense that a real person is behind the written text, whether the reader knows who the writer is or not. In the same vein, Ivanic and Camps (2001) emphasised voice not only in writing but also in all aspects of human activities.

Writing is regarded as a key factor in students' development. Researchers have started to pay a great deal of attention to socio-linguistic and communicative aspects of students' writing, in addition to linguistic ones, which are parts of the students' writing competence (Connor \& Mbaye, 2002). Accordingly, one of the goals should be improving 
communicative competence in L2 students by helping them to develop their voice in relation to whom they write (Kaplan \& Ramanathan, 1996). Voice as a communicative aspect of writing competence has not been sufficiently attended to in L2 writing evaluation and instruction (Connor \& Mbaye, 2002). To do so, it necessitates providing students with different contexts and, consequently, various genres. As Cummins (1994) noted, this voicing is "a process of continually creating, changing and understanding the internal and external identities that cast us as writers, within the confines of language, discourse, and culture" (p. 49).

The writer's voice differs based on the type of the text, the audience, and the purpose of the text. Expectations of readers also affect the writer's use of voice (Stock \& Erik-Nes, 2016). Some texts are written in a writing class to make the writing and other language skills better, while other texts are means for the writer to transmit knowledge in the field and become a member of that discipline by having his or her own voice; besides, there are also texts such as assignments that are written to get a grade; genres falling under these categories allow the use of various types of voice by writers (Stock \& Erik-Nes, 2016).

The textual features that are key elements in developing authorial voice have also been accentuated by empirical and descriptive studies (Hyland, 2008, 2010, 2011; Ivanic \& Camps, 2001; Matsuda, 2001; Matsuda \& Tardy, 2007). Therefore, by comparing the number of times these linguistic and discourse features occur among different writers and writer groups, they reveal how different writers and discourse communities use these linguistic features differently (Zhao, 2017). In one study, Zhao (2013) showed that voice is significantly associated with text quality. He applied the three-dimensional analytic voice rubric to measure voice. He concluded that the ideational dimension had a significant role and was a strong predictor of text quality. As a result, the ideational voice dimension was recognized as a key feature associated with L2 argumentative essays (Zhao, 2017). The findings of Zhao's research help students equip their writing with logical and persuasive arguments by using clear reasoning and fascinating opinions based on their own thinking and logic. Therefore, in the present study, the researchers focused on analysing essays types advanced Iranian language learners produced as their class assignments. We, specifically, explored voice features among narrative, descriptive, and argumentative essays under timed and untimed conditions to ensure if the conditions under which essays were produced affected the various voice features included in the essay types.

\section{Literature review}

\section{Notion of Voice}

Voice has an elusive nature which results in being considered a concept which is intriguing and perplexing difficult to clarify (Zhao, 2013). Morton and Storch (2019) 
defined voice as the "ability to marshal information from sources in a way that goes beyond that sort of dutiful listing of things making it clear to the readers what was their voice or other people's voices" (p. 6).

As an identity marker, voice can differentiate people from others by its uniqueness in spoken interactions (Bowden, 1995; Ivanic \& Camps, 2001). Although voice plays a key role in speaking, voice in texts is considered to be more complicated because voice features in writing are not as clear as those in spoken texts.

It is not possible to restrict 'self-representation' to the writing style since it is integrated with the activities of an individual. To provide an example, if we imagine a person entering a room, his self-representation can be conveyed through his clothes, types of shoes, the angles of his head, his facial expressions such as smiles, and their eye contacts with people (Ivanic \& Camps, 2001). Such non-verbal resources can indicate their social group or their situation of certainty and authority, and they can also provide information about their relationships with others and uncover the nature of their feeling about the events they are taking part in without even opening their mouth (Ivanic \& Camps, 2001).

As Riyanti (2015) argues, "similar to the notion of voice in spoken interaction in which it is part of the identity marker of the speakers, voice in writing also serves similar functions related to the identity of the writers" (p. 31). As writers, we have this ability to show who we are just by the choice we make in the texts the same way as we choose our clothes, our speech, or body language; however, these self-representations are not constructed from an infinite range of possibilities, but taken from culturally available resources when we write (Hyland, 2008).

\section{Voice as Individual Representativeness}

Voice is an aspect included in various features of identity (Tardy, 2016). Although scholars have generally shifted to social constructivist viewpoints, considering voice to be both individual and social, some studies have represented the prevalence of an expressivist view of voice as a property of a writer who is regarded to be unique and controlled solely by the writer (Tardy, 2016). Tardy found the most frequent conceptions of voice, which consisted of expression of opinion, authorial presence, and personal experience through interviews of master's degree students in Central Europe.

Sperling et al. (2011) debate that "the connection of voice to the self supports the connection of writing as a kind of identity performance" (p. 72). With this approach, voice is the individual performance that enables writers to reveal their real selves by applying particular linguistic features in the text (Riyanti, 2015).

Another study by Jeffry (2009) had similar findings by interviewing secondary school teachers who took the view of voice to be expressivist and linked it to authorial presence, resonance and authenticity. The term 'unique inner self' was first used by Ramanathan 
and Atkinson (1999), who mentioned the expressivist description of voice which was rooted in an individualist's conception (Tardy, 2016).

\section{The Significance of Voice}

It is widely believed that the presence of individual voice is a vital factor of good writing, and it is also believed that the voice of writers can be discovered if enough samples of free or expressive writings are collected and analyzed (Zhao, 2013). By using critical awareness in L2 writing pedagogy, we can teach learners how to control their individuality and culture while writing (Ivanic \& Camps, 2001).

Brook (2012) emphasized the authors' social context. In her study on adolescents from Harlem, she indicates the participants used their voice as a contributing factor in their writing to take part in the community and to depict their community more efficaciously (Riyanti, 2015).

\section{Voice in Academic Writing}

Undoubtedly, voice is a major feature of good writing, which is valued pedagogically by writing teachers in their instructions (Zhao, 2013). In one study with the aim of identifying voice in L2 writing, Ivanic and Camps (2001) found that L2 writers use voice in a way that they intend to position themselves in their writing; thus, this positioning is affected by many factors which result from the use of multiple voices in their writing. One of these factors can be the nature of the task and assignments they have to write (Riyanti, 2015).

Hyland (2010) did a comprehensive job in authorial voice markers with regard to disciplinary variations. Hyland applied linguistic devices (including hedges, boosters, evaluative markers) in writing in different disciplines. He conducted that self-mentions are used by students of humanities and science more frequently than those in hard sciences. Hyland related the differences to the epistemological variations in the discipline of case studies.

Studies examining identity and voice in compositions in multiple languages can provide great knowledge. One example could be Canagarajah (2004), who demonstrated how different the discursive strategies of self-representation of a Sri Lankan student were. Such multilingual competence was analyzed Tardy (2016), who found the expression of identity to be both similar and different in three languages she used. The multilingual students who enter academic writing courses are not voiceless because they are literate in their native language, and these students might have encounters with voice, though not explicitly or extensively (Belcher \& Hirvela, 2001).

As readers look for evidence rather than opinion, voice is unwelcome in academic writing; as a result, students learn to remove their persona when writing in scientific genres (Hyland, 2008). Thompson (2012) investigated the use of overrall and attribution and their contribution to developing authorial presence in $\mathrm{PhD}$ students' dissertations. 
The results obtained from this research indicated that doctoral students tried to show their an authorial presence in each part of their dissertations even in the macrostructure (Morton \& Storch, 2019).

The four selves of Roz Ivanic's framework of writer identity can contribute to better understanding of how the autobiographical self (the author's background) and the self as author (the way the authorial identity is projected in the text written by author) link to the discoursal self (the effect of rhetorical choices and linguistic forms the writers use (Menard-Warwick, 2005). Selfhood is the writer's capability to show the idea that personal voices fulfil the expectations in the disciplinary communities (Morton \& Storch, 2019). Hyland and Jiang (2016) observed that "personal judgements are convincing, or even meaningful, only when they contribute to and connect with a communal ideology or value system concerning what is taken to be interesting, relevant, novel, useful, good and so on" (p. 254).

There is a newly proposed model of academic writing voice proposed by Hyland. This model looks at the voice as an interaction between the author (presenting a personal stance and his/her audience (engaging and interacting with the intended readers), and also the model regards this interaction as being essential (Hyland, 2008). Regarding authorial stance and the reader's engagements and linking them with the model, the theory by Hyland (2008) highlights the construct aspects in both individualistic and interdependent manners and points to particular factors capturing voice (Zhao, 2013).

The findings of previous studies, as reviewed in the preceding paragraphs, show voice varies in writer types, text types, disciplines, and conditions under which it is reflected. Voice helps writers to take a stance regarding the propositions they add to their writing. Furthermore, voice features help writers engage readers in argumentation, interact with their readers, and present their ideas more convincingly. However, previous research studies have primarily focused on the analysis of voice features in published expert writing in single text types. Although this line of research has proved promising and sheds light on the conventions of expert writing, the examination of voice features does not give us a complete picture of how student writers use them in the essays they produce under timed and untimed conditions. The study of these features in student writing across text types provides researchers with insights into the ways they manipulate language to create effects on readers. The present study was aimed at filling this gap.

\section{Methods}

\section{Participants}

The participants involved in the research were 100 Iranian English language learners studying Certificate at Advanced levels (CAE) at Afaq language institute in Tehran, Iran. 
The rationale for selecting the CAE participants was due to their advanced proficiency levels in this language center. The participants in this study were selected through convenience sampling based on availability among advanced CAE learners of various branches of Afaq language institute in Tehran. The participants were in intact classes studying Objective advanced textbooks, majoring in different fields in high school or university. Thirty-seven male and 63 female learners were selected to participate in this study. Their age range was between 17 and 25, and their native language was Persian.

\section{Instruments}

The essays in this study were timed and untimed essays. The timed essays asked the student writers to depict the disciplinary knowledge by writing a sample within a limited period of time while sitting their final exam; however, the untimed essays were those the learners produced as a homework assignment, no matter how long it took the learners to write. They are 4-plus paragraphs, which means they are primarily four paragraphs long, but they can be longer as far as they follow an introduction, a body, and a conclusion. The participants wrote the essays in three genres of expository, argumentative, and descriptive.

Studies, so far, have used similar rubrics to measure voice. Some famous ones include: DiPardo et al. (2011) Voice (Stance) category rubric, Zhao's (2013) Analytic Voice Rubrics, and Helms-Park and Stapleton's (2003) Voice Intensity Scale. The current study used the same three rubrics to score descriptive essays, argumentative essays, and expository essays, respectively.

Passion, perspectives, support, and awareness of the writer were best seen in descriptive writing. That is why DiPardo et al. (2011) rubric was selected to measure voice in descriptive texts. This rubric includes a holistic approach to evaluate voice, and the scores range from 1 to 6 . One is the weakest score point, reflecting the absence of voice and 6 is the strongest score point, showing the fullest demonstration of voice. Voice in this model is particularly scored by the extent to which audience awareness and engagement with the topic are achieved and how the other writing elements are used to develop a sense of authorial presence. In this model, focus is more on textual features.

Zhao's (2013) rubric was employed to evaluate voice in argumentative essays due to its accuracy and precision. Since it is an analytic rubric, in spite of the difficulty of scoring, it is used to enhance interrater reliability. The scoring rubric consisted of three dimensions; each dimension was evaluated on a scale of 1 to 5 , showing the range from the absence of a particular feature to the use of the same feature extensively in the writing sample. It is worth noting that Zhao's rubric considers the point of view and clear stance as the key features of argumentative writing.

Zhao (2013) developed and validated a scale on the basis of Hyland's (2008) theoretical model, which measures voice strength in second language L2 argumentative writing through the following dimensions: (1) the presence and clarity of ideas in the content 
(dimension 1); (2) the manner of the presentation of ideas (dimension 2); (3) the writer and reader presence (dimension 3). This study used the same rubric to measure significant voice features other than voice strength. It should be noted that the presence or absence of a central point affects getting a clear voice in argumentative writing and the most important element in realizing voice for the rater. Therefore, central point articulation and the use of directives were considered components of dimension 1, and "presence and clarity of ideas in the content" (Zhao, 2013, p. 2).

In Zhao's study, hedges, attitude markers, and boosters were largely associated with one component which is called "manner of presentation" (dimension 2). In fact, by using these linguistic devices, the writer shows if he or she offers his viewpoints and arguments assertively, confidently, mildly, tentatively, enthusiastically, or indifferently. In dimension 2 , the selection of linguistic markers of essay structure, attitude markers, and choice of adjectives and verbs contributed to the raters and the readers' perception of the level of voice strength in general. In the same study, the writer and reader presence (dimension 3) was manifested through the use of other components such as authorial self-mention and direct reader reference.

\section{Research Design}

The present study was quantitative in methodology and pre-experimental in research design. The researchers used the quantitative paradigm to drive them to carry out the present research for the following two reasons: (1) rubrics were used to collect numerical data, and (2) the data were analysed using a series of parametric tests. This study was pre-experimental in design because language learners were not randomly selected, they were not assigned to experimental and control groups, and no treatment was used.

\section{Data Analysis}

After the data collection procedure was finalised, to test the research hypotheses and to answer the research questions, the present research used a within-subject repeated measures Analysis of Variance (ANOVA) to compare the timed and untimed four components of the expository writing as the expository writing is comprised of two within-subject factors: Time and four components of expository. Besides, the post-hoc comparison tests were run to compare the four subsets of expository writing two by two. Likewise, a within-subject repeated measures ANOVA was applied to compare the timed and untimed components of argumentative writing. The argumentative writing is comprised of two within-subject factors too: Time factor and three dimensions of argumentative writing. Finally, a paired-samples $t$-test was used to compare the timed and untimed descriptive writings. 


\section{Results}

To answer the first research question which asked if there were any significant differences in voice features among advanced student writers' timed and untimed expository writing's four subsets (assertiveness, self-identification, reiteration, and authorial presence), a within-subject repeated measures ANOVA was used to compare the timed and untimed four sets of the expository writing.

Table 1 displays three $F$-values briefly discussed. The results indicated that there were significant differences $\left(F_{(3,97)}=3.76, p<.05\right.$, Partial Eta Squared $=.104$ representing a moderate to large effect size) among the four types of expository writing, disregarding the Time factor. Based on these results, it can be concluded that the first null hypothesis "there were not any significant differences in voice features among advanced student writers' four subsets (assertiveness, self-identification, reiteration, and authorial presence) is rejected.

\section{Table 1}

Multivariate Tests: Expository Writing by Time by Type

\begin{tabular}{llcccccc}
\hline Effect & Value & F & $\begin{array}{c}\text { Hypothesis } \\
\text { df }\end{array}$ & $\begin{array}{c}\text { Error } \\
\text { df }\end{array}$ & Sig. & $\begin{array}{c}\text { Partial Eta } \\
\text { Squared }\end{array}$ \\
\hline \multirow{2}{*}{ Type } & Pillai's Trace & .104 & 3.763 & 3 & 97 & .013 & .104 \\
& Wilks' Lambda & .896 & 3.763 & 3 & 97 & .013 & .104 \\
& Hotelling's Trace & .116 & 3.763 & 3 & 97 & .013 & .104 \\
& Roy's Largest Root & .116 & 3.763 & 3 & 97 & .013 & .104 \\
\hline
\end{tabular}

Table 2 shows the descriptive statistics for four subsets of expository writing without including the Time factor. The results indicated that the participants had the highest performance on self-identification $(M=4.08)$. This was followed by reiteration $(M=4.05)$, authorial presence $(M=4.01)$ and assertiveness $(M=3.95)$.

Table 2

Descriptive Statistics; Four Types of Expository Writing

\begin{tabular}{lcccc}
\hline \multirow{2}{*}{ Type } & \multirow{2}{*}{ Mean } & \multirow{2}{*}{ Std. Error } & \multicolumn{2}{c}{ 95\% Confidence Interval } \\
\cline { 4 - 5 } & & & Lower Bound & Upper Bound \\
\hline Assertiveness & 3.958 & .039 & 3.880 & 4.035 \\
Self-Identification & 4.085 & .049 & 3.988 & 4.182 \\
Reiteration & 4.055 & .054 & 3.948 & 4.162 \\
Authorial Presence & 4.018 & .054 & 3.910 & 4.125 \\
\hline
\end{tabular}


The second research question asked if there were any significant differences in voice features among advanced student writers' timed and untimed argumentative writing's three subsets (The ideational dimension (D1), the affective dimension (D2), and the presence dimension (D3)). A within-subject repeated measures ANOVA was run to compare the timed and untimed components of argumentative writing. The argumentative writing is comprised of two within-subject factors: Time factor and Dimension factor. The Time factor is divided into two sub-branches: timed and untimed, and the Dimension factor has three dimensions. SPSS, as it will be discussed below, produces three $F$-values for such designs: $F$-value for the effect of the Time factor, $F$-value for the effect of Dimension factor and $F$-value for the interaction between these two factors.

Table 3 displays the three $F$-values briefly discussed above. The results indicated that there were not any significant differences $\left(F_{(2,98)}=1.86, p>.05\right)$ between the three dimensions of argumentative writing, disregarding the Time factor. Thus, the second null hypothesis "there were not any significant differences in voice features among advanced student writer's argumentative writing subsets (The ideational dimension (D1), affective dimension (D2), and the presence dimension (D3))" was supported.

Table 3

Multivariate Tests for Argumentative Writing by Time by Dimension

\begin{tabular}{llcccccc}
\hline & Effect & Value & F & $\begin{array}{c}\text { Hypothesis } \\
\text { df }\end{array}$ & $\begin{array}{c}\text { Error } \\
\text { df }\end{array}$ & Sig. & $\begin{array}{c}\text { Partial Eta } \\
\text { Squared }\end{array}$ \\
\hline \multirow{6}{*}{ Dimension } & Pillai's Trace & .037 & 1.863 & 2 & 98 & .161 & .037 \\
& Wilks' Lambda & .963 & 1.863 & 2 & 98 & .161 & .037 \\
& Hotelling's Trace & .038 & 1.863 & 2 & 98 & .161 & .037 \\
& Roy's Largest Root & .038 & 1.863 & 2 & 98 & .161 & .037 \\
\hline
\end{tabular}

Table 4 displays the descriptive statistics for three dimensions of argumentative writing without including the Time factor. The results indicated that the participants had almost the same means on first $(M=3.54)$, second $(M=3.58)$, and third $(M=3.48)$ dimensions of argumentative writing.

\section{Table 4}

Descriptive Statistics; Four Dimensions of Argumentative Writing

\begin{tabular}{lcccc}
\hline \multirow{2}{*}{ Dimension } & \multirow{2}{*}{ Mean } & Std. Error & \multicolumn{2}{c}{ 95\% Confidence Interval } \\
\cline { 4 - 5 } & & & Lower Bound & Upper Bound \\
\hline First Dimension & 3.540 & .063 & 3.415 & 3.665 \\
Second Dimension & 3.588 & .054 & 3.481 & 3.694 \\
Third Dimension & 3.485 & .054 & 3.377 & 3.593 \\
\hline
\end{tabular}


In order to answer the third research question (Are there any significant differences in voice features among advanced student writers' timed and untimed descriptive writing?), a paired-samples $t$-test was run to compare the participants' means on the timed and untimed descriptive essays. Based on the results displayed in Table 5, it can be claimed that the students had almost the same means on timed $(M=3.47)$ and untimed $(M=3.45)$ descriptive writing.

\section{Table 5}

Descriptive Statistics for Timed and Untimed Descriptive Writing

\begin{tabular}{lcccc}
\hline & Mean & N & Std. Deviation & Std. Error Mean \\
\hline Timed & 3.47 & 100 & .656 & .066 \\
Untimed & 3.45 & 100 & .669 & .067 \\
\hline
\end{tabular}

The results of the paired-samples $t$-test $\left(t_{(99)}=.615, p>.05\right)$, as shown in Table 6 , indicated that there was not any statistically significant difference between timed and untimed descriptive writing. Thus the third null-hypothesis was supported.

Table 6

Paired-Samples t-test for Timed and Untimed Descriptive Writing

\begin{tabular}{|c|c|c|c|c|c|c|c|}
\hline \multicolumn{5}{|c|}{ Paired Differences } & \multirow{3}{*}{$\mathbf{t}$} & \multirow{3}{*}{ df } & \multirow{3}{*}{$\begin{array}{c}\text { Sig. } \\
\text { (2-tailed) }\end{array}$} \\
\hline \multirow{2}{*}{ Mean } & \multirow{2}{*}{$\begin{array}{c}\text { Std. } \\
\text { Deviation }\end{array}$} & \multirow{2}{*}{$\begin{array}{l}\text { Std. Error } \\
\text { Mean }\end{array}$} & \multicolumn{2}{|c|}{$\begin{array}{l}\text { 95\% Confidence Interval of the } \\
\text { Difference }\end{array}$} & & & \\
\hline & & & Lower & Upper & & & \\
\hline .021 & .342 & .034 & -.047 & .089 & .615 & 99 & .540 \\
\hline
\end{tabular}

\section{Discussion}

The first finding of this study showed statistically significant differences between timed and untimed expository essays, and the learners performed significantly better under untimed conditions than they did under timed conditions. Time pressure is a constraining force or influence that can psychologically persuade some learners to behave and think differently (Orfus, 2008). We speculate that one possible explanation for this outcome is that, when learners are under time constraints, they perform more poorly on a cognitive task (Tobis, 1985), whose findings was also confirmed in Lee (1995), who suggested that people have less working memory capacity available because space is overloaded with worry and interfers with a person's cognitive processing abilities.

The second finding of this study revealed that there were not any statistically significant differences between timed and untimed argumentative essays. The difference in the 
scores between timed and untimed essays implies that the students might be conflicted regarding when to apply quick versus slow, careful analysis strategies in writing (Tobias, 1985). It also shows that there were no significant differences among the three dimensions of argumentative writing. The results showed that the participants performed almost the same on the ideational (D1), the affective (D2), and the presence dimension (D3) of argumentative essays when the time factor was kept constant.

Presention of ideas and claims that show authority and confidence, the tone of the writing, and the writers' attitude toward the topic under discussion contribute to the manifestation of authorial voice in affective dimension in argumentative essays and give the reader a sense of who the writer is, shares personal background and experience with the reader, and shows the presence in argumentative essays (Yoon, 2017).

When the time was taken into consideration and the effect of time was controlled for in the present study, time mainly affected the four components of writing ability (topic relevance, content development, organization and coherence, and language use). The results showed that there was a statistically significant difference between timed and untimed argumentative essays. That is, the participants were more involved in untimed essays than in timed essays. However, in terms of timed and untimed essays, the findings of the present study are not in line with those of some previous studies. For instance, Adel (2008) examined engagement markers in timed and untimed sections. The results of the study showed that the learners exhibited more involvement in timed than in untimed essays. One possible explanation for the difference between the findings of the present study and those of Adel (2008) can be the number of studied factors in both studies. It is worth noting that the number of factors considered in Adel's (2008) study is only involvement while in the present study more than one factor was examined.

One possible justification for the finding of the present study in this regard might be the less cognitive burden due to the lack of time pressure. It seems that, when students write about a relevant topic, develop, argue and organise content coherently and use language correctly, they may perform better when more time is given. However, there could be some interfering factors which could be considered. Time pressure coupled with exam stress and test anxiety usually impairs performance, so students have difficulty developing the given topic and elaborating on details to express a clear and coherent argument. The presence and salience of authorial voice may be closely and significantly associated with time.

The findings of the study confirm those of Zhao (2017), who studied the relationship between argumentative essay writing and voice features on timed essays. All of the dimensions of voice, when examined alone, presented strong positive relation with TOFEL scores on argumentative essays. This suggests the probability of the aspect of voice presence being associated with raters' understanding of text quality in L2. Nevertheless, regression analysis showed the statistical significance of ideational dimensions only influenced the text quality, when the effects of other dimensions of voice were controlled. The result of 
this study reveals that voice can be regarded as a predictor of scores TOFEl writing. She concluded that the content-related voice dimension is an integral part of L2 argumentative writing quality. Accordingly, the instructors should not teach the features separately.

The last finding of the study was that no statistically significant differences were found between timed and untimed descriptive essays. The results showed students performed similarly on timed and untimed descriptive essays. Demonstration of an evident and clear perspective, the use of sophisticated style to communicate stance and attitude, and application of interesting and appropriate tone are the components to be considered in descriptive essays. Comparing the components of the three genres, the components of descriptive essays do not need reasoning and arguing. In a study by Olinghouse and Wilson (2013), they examined the fifth grade writing and the results indicated that argumentative and persuasive essays were written with greater lexical diversity and in a higher register than descriptive essays. This could be one possible reason why no significant effect was found.

\section{Conclusions}

According to the findings of the present study, it is concluded that self-identification can be a statistically significant factor in expository essays. Such a conclusion shows that in the context of expository essay writing, the use of linking words and the use of first person singular pronoun along with active voice construction are integral parts of voice making and might also be the most crucial factors contributing to CAE raters' positive evaluation of features in L2 expository essay. One of the major points which teachers work on, from the beginning of learning English, is personalisation. This is worked on in oral reproduction and written language. That is why almost all of the students are competent in using their own ideas and opinions on various issues.

The second conclusion drawn from the findings of the present study is that assertiveness is also a statistically important genre-related factor. It is an integral factor contributing to the raters in the evaluation of the text. Unfortunately, Iranian student writers never, or rarely used, intensifiers to strengthen their claims. They slightly conveyed their opinion or alleged their strong commitment to assertions and did not avoid using hedges to strengthen their claims.

The third conclusion of this study is that, generally, in discussing voice and the importance of its features, certain key factors play a much more important role. It has been seen that in some genres when time is considered a factor like expository writing, the participants have a better performance in untimed writings. Since time is one of the assessing criteria in examinations, particularly in international examinations, it should be taken into consideration as an important factor in writing classes. We must bear in mind that time is not a major issue when students do not know much about writing 
strategies. If students do not know the writing strategies well, the results will not vary very much no matter how much time they are given.

Argumentative and expository essays have special layouts and formats. Such layouts and formats are wider and freer in descriptive essays. That is one of the main reasons for which students had similar scores in timed and untimed descriptive essays. To describe something or somebody, all a student needs is vocabulary. Besides, the students are free to explore the topic. On the contrary, in expository writings, for instance, there is a need for a topic sentence in any paragraph as the framework for this type of writing. Besides, there is a necessity for the presence of supporting facts and examples in order to develop the ideas.

Overall, the findings from this study contribute to L2 writing in the following ways, and this is where our study can bring new knowledge. First, voice features differ significantly from one student's text type to another one, and voice is very much conditioned by the conventions of writing. Therefore, genre plays a key role in helping students to raise their awareness regarding which text type they write about, making it much thicker. Second, voice is a multi-faceted construct which may be mediated by time factor. When student writers are given free time (when they are not under time constraints) to write about a prompt, they can hone their writing skills, using voice features as linguistic elements to hedge their claims, to argue more persuasively, and to interact with readers more effectively.

The findings of the present study carry some implications for L2 pedagogy and instruction. To begin with, when voice features in text types are identified and made more explicit, the writing inquiry opens the possibility for critical self-understanding that can help students maintain their integrity and rigor in their writing. By making the practices explicit, this also makes visible the tacit understanding of each genre shared by users, paving the way for teachers to know what is required for these features to become recognised as new conventions. Second, the recognition of the complexity of assertiveness and acknowledgment of intensifiers and hedges are valued, helping students to fine-tune their texts to be convincingly more effective. Last, but not least, writing instructors highlight the importance of time management and teach students how to manage time when composing different text types. By introducing the significant voice features, the 'unlearnable' features can somewhat be broken down into smaller components which are comparatively more concrete and discrete, and can demystify, even if only to some extent, the seemingly view point that voice features are linguistic elements that could be looked at holistically.

Like other research studies, the present study includes some limitations which the researchers outline in this paragraph. Although voice features lend themselves readily to quantitative analysis, using a follow-up interview to seek language learners' opinions about their choice of certain features in one text type than the other one would provide us with more exploratory reasons, complementing quantitative data and contributing to 
a thick description. We limited our study to language learners at the institutional level, given the limited access we had. Selecting participants representing various learner groups from various educational backgrounds will offer more insight into the behaviour of voice features across learner groups. The final limitation of our study was that we did not distinguish between male and female language learners. Gender may affect the use of voice features.

\section{References}

Adel, A. (2008). Involvement features in writing: Do time and interaction trump register awareness? Language and Computers Studies in Practical Linguistics, 66(1), 35-52.

Belcher, D., \& Hirvela, A. (Eds.). (2001). Voice in L2 writing. Journal of Second Language Writing, 10(2), 1-138.

Bowden, D. (1995). The rise of a metaphor: Voice' in composition pedagogy. Rhetoric Review, 14(1), 173-188.

Brook, R. (2012). Voices of young citizens: Rural citizenship, schools, and public policy. In K. Donehower, C. Hogg, \& E. Schell (Eds.), Reclaiming the rural: Essays on literacy, rhetoric, and pedagogy (pp. 161-172). Carbondale, IL: Southern Illinois University Press.

Canagarajah, S. (2004). Multilingual writers and the struggle for voice in academic discourse. In A. Blackledge \& A. P. Clevedon (Eds.), Negotiation of identities in multilingual contexts (pp. 266-89). UK: Multilingual Matters Ltd.

Connor, U., \& Mbaye, A. (2002). Discourse approaches to writing assessment. Annual Review of Applied Linguistics, 22(1), 263-278.

Cummins, G. S. (1994). Coming to voice. In K. B. Yanncy (Ed.), Voices on voice: Perspectives, definitions, inquiry (pp. 48-60). Urbana, IL: National Council of Teachers of English.

DiPardo, A., Storms, B. A., \& Selland, M. (2011). Seeing voices: Assessing writerly stance in the NWP analytic writing continuum. Assessing Writing, 16(3), 170-188.

Helms-Park, R., \& Stapleton, P. (2003). Questioning the importance of individualized voice in undergraduate L2 argumentative writing: An empirical study with pedagogical implications. Journal of Second Language Writing, 12(3), 245-265.

Hirvela, A., \& Belcher, D. (2001). Coming back to voice: The multiple voices and identities of mature multilingual

Hyland, K. (1998). Hedging in scientific research articles. Journal of Applied Linguistics, 3(2), 133-136.

Hyland, K. (2008). Disciplinary voices: Interactions in research writing. English Text Construction, $1(1), 5-22$.

Hyland, K. (2010). Community and individuality: performing identity in applied linguistics. Written Communication, 27(2), 159-188. 
Hyland, K. (2011). The presentation of self in scholarly life: Identity and marginalization in academic homepages. English for Specific Purposes, 30(4), 286-297.

Ivanic, R., \& Camps, D. (2001). I am how I sound: Voice as self-representation in L2 writing. Journal of Second Language Writing, 10(1-2), 3-33.

Jeffery, J. (2009). Constructs of writing proficiency in US state and national writing assessments: Exploring variability. Assessing Writing, 14(1), 3-24.

Kaplan, R. B., \& Ramanathan, V. (1996). Audience and voice in current L1 composition texts: Some implications for ESL student writers. Journal of Second Language Writing, 5(1), 21-34.

Lee, J. (1995). Information processing model of text anxiety and its effect on the speed-accuracy trade-off (ACT or the spreading activation explanation). Paper presented at the Annual Meeting of the American Education Research Association, San Francisco, CA.

Matsuda, P. K. (2001). Voice in Japanese written discourse: Implications for second language writing. Journal of Second Language Writing, 10(1-2), 35-53.

Matsuda, P. K., \& Tardy, C. M. (2007). Voice in academic writing: The rhetorical construction of author identity in blind manuscript review. English for Specific Purposes, 26(2), 235-249.

Menard-Warwick, J. (2005). Both a fiction and an existential fact: theorizing identity in second language acquisition and literacy studies. Linguistics and Education, 16(3), 253-274.

Morton, J., \& Storch, N. (2019). Developing an authorial voice in $\mathrm{PhD}$ multilingual student writing: The reader's perspective. Journal of Second Language Writing, 43, 15-23.

Orfus, S. (2008). The effect of test Anxiety and time pressure on performance. The Hurdon University College Journal of Learning and Motivation, 46(1), 118-133.

Ramanathan, V., \& Atkinson, D. (1999). Individualism, academic writing, and ESL writers. Journal of Second Language Writing, 8(1), 45-75.

Riyanti, D. (2015). An exploration of voice in second language writing. The Nebraska Educator, 2(1), 28-48.

Sperling, M., Appleman, D., Gilyard, K., \& Freedman, S. (2001). Voice in the context of literacy studies. Reading Research Quarterly, 46(1), 70-84.

Stapleton, P. (2002). Critiquing voice as a viable pedagogical tool in L2 writing: Returning the spotlight to ideas. Journal of Second Language Writing, 11(3), 177-190.

Stewart, D. C. (1992). Cognitive psychologists, social constructionists, and three nineteenthcentury advocates of authentic voice. Journal of advanced Composition, 12(2), 279-290.

Stock, I., \& Eik-Nes, N. L. (2016). Voice features in academic texts-A review of empirical studies. Journal of English for Academic Purposes, 24 (1), 89-99.

Tardy, C. M. (2016). Voice and identity. In R. M. Manchon \& P. K. Matsuda (Eds.) Handbook of second and foreign language writing (pp. 349-363). Berlin: Mounton de Gruyter.

Thompson, P. (2012). Achieving a voice of authority in PhD theses. In K. Hyland \& C. S. Guinda (Eds.), Stance and voice in genres (pp. 119-133). London: Palgrave Macmillan.

Tobias, S. (1985). Text anxiety: Interference, defective skill, and cognitive capacity. Educational Psychologist, 20(3), 135-142. 
Yoon, H. J. (2017). Textual voice elements and voice strength in EFL argumentative writing. Assessing Writing, 32(1), 72-84.

Zhao, C. G. (2013). Measuring authorial voice strength in L2 argumentative writing: The Development and validation of an analytic rubric. Language Testing, 30(2), 201-230.

Zhao, C. G. (2017). Voice in timed L2 argumentative essay writing. Assessing Writing, 31(1), 73-83.

\title{
Besimokančiųų (pažengusiuju) anglų kalbos, kaip antrosios užsienio kalbos, nuomonès ypatumai esẻ tipo rašiniuose
}

\author{
Rajab Esfandiari ${ }^{1}$, Hananeh Sharifi ${ }^{2}$ \\ 1 Imamo Khomeini tarptautinis universitetas, Anglų kalbos katedra, Humanitarinių mokslų fakultetas, PC, \\ IRN-34148-96818 Kavzinas, Iranas, esfandiari@hum.ikiu.ac.ir \\ 2 Imamo Khomeini tarptautinis universitetas, Anglų kalbos katedra, Humanitarinių mokslų fakultetas, PC, \\ IRN-34148-96818 Kavzinas, Iranas, hannanehsharifi951@gmail.com
}

\section{Santrauka}

Ankstesni tyrimai parode, kad rašytojai linkę laikytis idejų, kurias iškelia savo rašiniuose, apmąsto, vertina ir taip išsako savo nuomonę. Tačiau studentai, kurie rašo rašinius, paprastai nesugeba kritiškai ịvertinti esė turinio. Šio tyrimo tikslas buvo išanalizuoti Irano studentų, besimokančių anglų kalbos, nuomonę ìvairiuose esė - aiškinamosiose, aprašomosiose ir argumentuotose - tipuose tam tikromis ir nenumatytomis sąlygomis. Šio tyrimo duomenims rinkti buvo naudojamos penkių pastraipų esè. Duomenys buvo analizuojami naudojant SPSS (25 versija). Pakartotinių dispersijų matų analizès (ANOVA) rezultatai parodè statistiškai reikšmingus nuomonių skirtumus aiškinamosiose esè, bet jų neparodè argumentuotose esė, kurios buvo parašytos limituotu ir nelimituotu laiku. Suporuotų pavyzdžių $t$ testo rezultatai neparodė statistiškai reikšmingų nuomonès skirtumų aprašomosiose esé, kurios buvo parašytos limituotu ir nelimituotu laiku. Išvados rodo, kad skirtingųžanrų nuomonės ypatybių analizè suteikia žinių rašantiems, kaip jie sẻkmingai gali išlaikyti balansą tarp savų perspektyvų pristatymo, kitų perspektyvų pripažinimo ir efektyvaus ịvertinimo, kokią perspektyvą priims jų skaitytojai. Straipsnyje aptariama, kaip anglų kalbos besimokantieji turi efektyviai išsakyti nuomonę savo rašiniuose.

Esminiai žodžiai: nuomonè, esè tipas, išdèstymas, limituoto laiko esé, nelimituoto laiko esè. 